
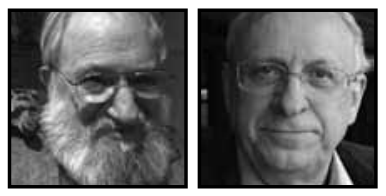

\title{
Commentary
}

\section{The State of Learning: A Preview}

\author{
Seymour Papert, Massachusetts Institute of Technology \\ George Markowsky, University of Maine
}

\section{ABSTRACT}

This article gives some background information on the authors' forthcoming book, The State of Learning. There are many challenges facing educators who want to bring education into the 21st century. At the same time, the explosion of technology has the potential to make education more available and influential than ever before. Education is taking place on a large stage and is not just confined to schools. We must rethink the foundations of education so it can truly benefit from new technology.

earning has moved into center stage of public debate and private concern. Never has there been such concern about education, so much worry about its problems, so much excitement about new prospects, so many ideas generated, so much money spent, and so many developments that dramatically demonstrate that learning is on the move. Yet, at the same time, never has there been such a tangle of confusion in public and private discussion about where it is going and about why so many schools and so many students are having so many difficulties.

We are writing a book called The State of Learning. This book focuses on the problems associated with reforming education and bringing it into the 21 st century. There has been a lot of talk about reforming education that has seemingly had little effect on the educational establishment. Yet change is coming. It is being driven by many factors and facilitated by technology. Change is coming because it is no longer possible to do things the way we used to do them, because a student in Bangladesh 
can freely access an online course from MIT, ${ }^{1}$ because an ever-growing number of people carry computers in their pockets, because computing and communication are challenging traditional methods of knowledge collection and dissemination, and because we simply can't afford to do business as usual. Big change really is inevitable. What is not inevitable is the way the big change will play out. Our book is about the megachange that is happening in the way the world thinks about education.

The State of Learning presents a unified approach to a wide range of aspects of learning. Although the book's primary emphasis will be on issues directly related to schools, it will devote chapters to the learning that takes place in the home, in the workplace, and in the virtual space of the Internet. The thesis of the book is that problems and opportunities in all these areas are profoundly misunderstood by being treated separately from one another and from large developments in society. The fragmentation of issues allows narrow specialists and interest groups to apply incompatible "remedies" that in the end aggravate the problems they seek to solve.

Our book gives the reader a bold and rigorously realistic vision of where learning might be going in the next decades and offer concrete strategies for dealing with immediate problems faced by schools, by families, and by the "knowledge society" at large. Many factors hold out the promise that ours could be the best of times for a flourishing of learning at all levels from early childhood through formal schooling to lifelong learning for work, for fun, or for a richer quality of life. With startling rapidity, every year sees the emergence of new forms of learning made possible by powerful new technologies. The past half-century has seen a burgeoning of theories capable of guiding further developments. Many futurists looking at these developments declare the arrival of the learning millennium.

But the bright picture is only one side - the best side-of a complex story. The worst side is represented by drugs ${ }^{2,3}$ and violence ${ }^{4,5}$ in schools, by epidemics of "learning disabilities," by growing disparities of opportunity, and by a growing abandonment of public education for home and privatized schooling. ${ }^{6,7}$

A narrow concept of "special ed" is strangling the budgets of many school districts, causing intense worry to many parents and contributing to the flight from public schooling. Dysfunctional responses currently favored by the Education Establishment hide the problems by the shocking practice of drugging millions of children labeled on the basis of flimsy research as organically hyperactive and by redefining learning as learning to score on superficial tests. The consequences go far beyond the unconscionable harm being done to children who are doomed for life to regard 
themselves as learning disabled. The disruptions of classrooms and the perversion of educational values affect all children, drive away many of our best teachers, and undermine the originality and intellectual spirit that is necessary for greatness.

In the midst of these grave problems there is profligate waste of resources and opportunities. The State of Learning focuses special attention on understanding why the vast majority of schools seem to be unable to use digital technologies, ${ }^{8}$ which in principle hold the key to an unprecedented liberation of human learning potential for purposes that go beyond the trivial.

Our diagnosis of the principal cause of School's problems is a deep and everwidening gap between school and society. Society is changing at an accelerating pace. School remains lethargically stuck with structures that took form in the 19th century with the result being that school now teaches obsolete skills that are not what is needed to make the best of life and learning in our new century. Far more serious is the social disaffection that comes in the wake of the growing perception among children that school is out of touch and grotesquely out of sync with the modern world that they experience every day. Increasing numbers of children are resisting learning what their parents learned not because they are learning disabled but because they do not see the point and find school boring and irrelevant. ${ }^{9}$

Yet our view of learning is optimistic. Understanding the gravity of the problems opens new ways to handling them. A central theme of our book is that the same failure of understanding that has blinded us to the causes of the malaise in learning also blinds education policy makers and the general public to the powerful means we can bring to bear on curing it. In particular it has led to a profound misunderstanding of the potential role of digital technology.

School's mishandling of technology is typical of a larger tendency. We examine the current responses to many problems facing schools and find that most actually aggravate the condition they seek to remedy. For example, if the problems facing School stem from the fact that it has changed so little, then the conservative "back to basics" solution of blaming and trying to reverse the little change that has taken place is an egregious example of a remedy that aggravates the disease. Less obviously but more invidiously, packing large numbers of computers into fundamentally unchanged schools falls into the same category. We argue that the entire structure of School, including its age segregation by grades and the content of its curriculum, is determined by outgrown characteristics of pre-digital age knowledge technologies. The attempted use of the computer to improve the obsolete system is akin to using the jet engine to improve transportation by attaching it to a stagecoach. 
The State of Learning offers concrete visions of what it might be like to invent the educational jet plane: new forms of learning that would effectively use our powerful technologies to meet the needs of our evolving society. These visions of what education will have to be like in a near future serve as a compass for realistic steps that can be taken now by policy makers, educators, and parents to prepare for that future. In short the question is: What can we do on Monday that will be a step towards "some day"?

\section{Notes}

1. MIT OpenCourseWare. Retrieved from http://ocw.mit.edu/index.htm

2. Attention Disorderor Not, Pills to Help in School, NYTimes, Oct. 9, 2012, Alan Schwarz. Retrieved from http://www.nytimes.com/2012/10/09/health/attention-disorderor-not-children-prescribed-pills-to-help-in-school.html?pagewanted=all\&_r=0

3. Ritalin: Miracle Drug or Cop-Out?, Frontline, Ken Livingston. Retrieved from http:// www.pbs.org/wgbh/pages/frontline/shows/medicating/readings/publicinter est.html

4. School violence shatters record, Yoav Gonen, Education Reporter, NY Post, August 29, 2012. Retrieved from http://www.nypost.com/p/news/local/school _violence_shatters_record_qmxszGXSerDsXDfoP2S8hK

5. Digest of Education Statistics: 2011. Retrieved from http://nces.ed.gov/programs/ digest/

6. Number of Homeschoolers Growing Nationwide, Julia Lawrence, Education News, May 21, 2012. Retrieved from http://www.educationnews.org/parenting/ number-of-homeschoolers-growing-nationwide/

7. Home Schooling in the United States: Trends and Characteristics, Kurt J. Bauman, Population Division, U.S. Census Bureau, August 2001, Working Paper Series No. 53. Retrieved from http://www.census.gov/population/www/documentation/ twps0053/twps0053.html 
8. Children, Teens, and Entertainment Media: The View From The Classroom, A National Survey of Teachers About the Role of Entertainment Media in Students' Academic and Social Development, Fall 2012. Retrieved from http://vjrconsulting.com/ storage/CSM_TeacherSurveyReport2012_FINAL.pdf

9. Teachers' Toughest Test? Student Apathy, They Say -- Class Size, Social Ills Also Mentioned, Jolayne Houtz, Seattle Times, March 1, 2013. Retrieved from http://com munity.seattletimes.nwsource.com/archive/?date $=19960904 \&$ slug $=2347453$

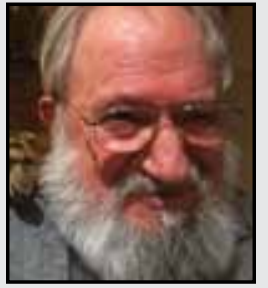

Seymour Papert is considered one of the world's foremost experts on how technology can provide new ways to learn. He has carried out educational projects on every continent, some of them in remote villages in developing countries. He participated in developing the most influential cutting-edge opportunities for children to participate in the digital world. His book, Mindstorms has been widely read and has influenced much thinking about education. Papert was instrumental in the One Laptop Per Child Project in convincing Maine to distribute laptops to all middle school children.

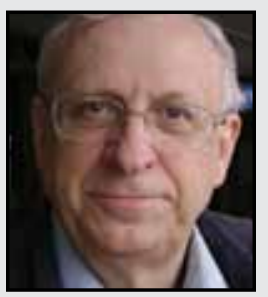

George Markowsky earned his PhD in Mathematics from Harvard University after which he spent 10 years working at the IBM T. J. Watson Research Center. Since leaving IBM, he has been a Professor of Computer Science at the University of Maine where he specializes in the development of algorithms, cybersecurity, and understanding the impact of technology on education. He has collaborated with Seymour Papert on a variety of projects related to technology and education, including the First Laptops, Learners and Powerful Ideas Conference at the University of Maine in 2002.

LINK TO:

http://DrGM.us 